\title{
Systemic infection of freshwater crayfish Cherax quadricarinatus by hymenostome ciliates of the Tetrahymena pyriformis complex
}

\author{
Brett Edgerton $^{1, *}$, Peter O'Donoghue ${ }^{2}$, Max Wingfield $^{3}$, Leigh Owens $^{1}$ \\ 'Department of Biomedical and Tropical Veterinary Sciences, James Cook University, Townsville 4811, Queensland, Australia \\ ${ }^{2}$ Department of Parasitology, The University of Queensland, Brisbane 4072, Queensland, Australia \\ ${ }^{3}$ Department of Fisheries, Primary Industries (South Australia), 25 Grenfell St., Adelaide 5000, South Australia, Australia
}

\begin{abstract}
A survey of cultured freshwater crayfish Cherax quadricarinatus in north Queensland revealed systemic infections by hymenostome ciliates in moribund crayfish from one location. The ciliates were identified following protargol impregnation as belonging to the Tetrahymena pyriformis species complex on the basis of their somatic and oral ciliature and morphometric characteristics. Live ciliates were observed in the haemal sinuses of the gills browsing on tissue fragments. Histological examination revealed the ciliates to have invaded most organs and tissues, causing extensive necrosis particularly in the hepatopancreas and antennal gland. Lipid reserves were not depleted in the hepatopancreas, suggesting the rapid development of acute disease. This is the first record of systemic ciliate infections in freshwater decapods.
\end{abstract}

KEY WORDS: Decapoda Cherax quadncarinatus - Ciliophora - Tetrahymena pyriforms - Morphology Histopathology

\section{INTRODUCTION}

Systemic infections by ciliated protozoa have only occasionally been recorded in crustacean hosts, most involving small scuticociliates in marine decapods ( $\mathrm{cf}$. review by Morado \& Small 1995). Several species of Mesanophrys (synonyms Mugardia, Paranophrys and Anophrys) have been described from crabs (Bang et al. 1972, Groliére \& Leglise 1977, Sparks et al. 1982, Morado \& Small 1994), one Anophryoides sp. from lobster (Cawthorn et al. 1996) and one Parauronema sp. from prawns (Couch 1978). In comparison, systemic infections by related hymenostome ciliates (including Ichthyophthirius, Cryptocaryon, Tetrahymena and Uronema spp.) occur more frequently in other aquatic hosts, particularly in fish and insect larvae (Elliott 1973. Lom \& Dykova 1992). A variety of other ciliates have been recorded in association with aquatic hosts, predominantly as endozoic or ectocommensal organisms (Corliss 1979).

·E-mail: brett.edgerton@jcu.edu.au
In the course of a disease survey of freshwater crayfish from commercial farms in north Queensland, systemic infections by hymenostome ciliates were detected in moribund Cherax quadricarinatus. This is the first record of a systemic ciliate in a freshwater decapod. This paper describes the morphological characteristics of the ciliate and the histopathological changes associated with infections

\section{MATERIALS AND METHODS}

A survey for pathogens of cultured redclaw crayfish Cherax quadricarinatus was conducted in north Queensland in 1993, and the results of the virological and bacteriological investigations have been presented elsewhere (Edgerton et al. 1995). During the survey, systemic infections by ciliates were detected in 3 of $32(9.4 \%)$ moribund crayfish from one location near Townsville. The crayfish exhibited weakened or failed tail-flick responses and were unable to right themselves when placed upside down. The crayfish 
were killed by severing the cephalothorax from the abdomen. The cephalothorax was fixed in Boun's fluid, and histological sections of the internal organs and tissues were prepared and stained with haematoxylin and eosin (H\&E) using routine procedures (Culling et al. 1985). Ciliates were detected in gill filaments of an additional moribund crayfish from the same farm by light microscopic examination of wet mounts counterstained with $0.2 \%$ toluidine blue. Infected gill filaments were fixed in Bouin's fluid, thoroughly washed in distilled water and the tissues teased apart to recover intact ciliates, which were then stained by protargol (silver proteinate) impregnation using standard techniques (Foissner 1991). Ciliates were examined by light microscopy, measured using a calibrated eye-piece graticule, drawn with the aid of a camera lucida and photographed in association with tissue lesions.

\section{RESULTS}

\section{Live observation}

Many ciliates were observed moving around in the haemal sinuses of the gills of the infected crayfish. The ciliates were variable in size, ranging from 30 to $75 \mu \mathrm{m}$ in length and from 20 to $50 \mu \mathrm{m}$ in width, but they were consistent in shape, being pyriform and slightly flattened anteriorly. The oral apparatus was located in a small subapical depression and the rest of the body was covered with short isokont cilia. The ciliates were granular in appearance due to the presence of numerous refractile vacuoles particularly in the posterior half of the body. A translucent contractile vacuole was also located in the posterior half of the body. The ciliates were highly motile and continually moved up and down the haemal sinuses while slowly rotating (predominantly clockwise) around their long axes. Individual ciliates were observed to feed on host tissues by circling around clumps of cells and ingesting small fragments as the cells disintegrated. The extent of their histophagous behaviour was evident when examining wet gill mounts over several hours. The ciliates readily consumed all the internal tissues, leaving only the outer cuticle. Cyst formation by the ciliates was not observed even when wet mounts became depleted of tissue or dried out.

\section{Silver impregnation}

Details of the oral and somatic ciliature were readily discerned in ciliates impregnated with protargol (Figs. 1 \& 2). Their key morphometric characteristics are presented in Table 1 . The ciliates contained a microstome oral apparatus consisting of a paroral membrane on the right and a tripartite adoral zone of membranelles on the left (Fig. 1). The somatic ciliature consisted of 20 to 26 longitudinal kineties arranged in meridional rows. All meridians extended to the anterior pole or the suture above the buccal apparatus except for 2 rows which only reached the posterior border of the buccal apparatus. By convention, the right postoral meridian is counted as the first kinety (K1). The ciliates possessed 1 to 2 contractile vacuole pores which were located posteriorly between kineties 5 and 6 . All the somatic cilia were uniform in

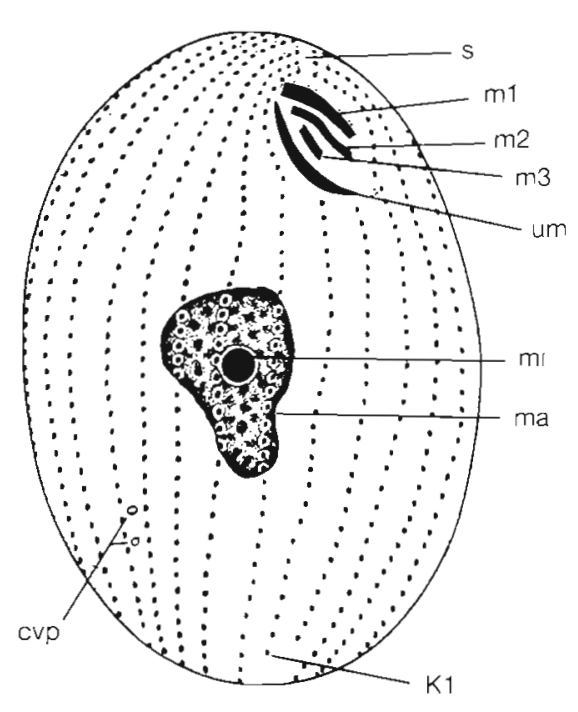

$R$ ventral
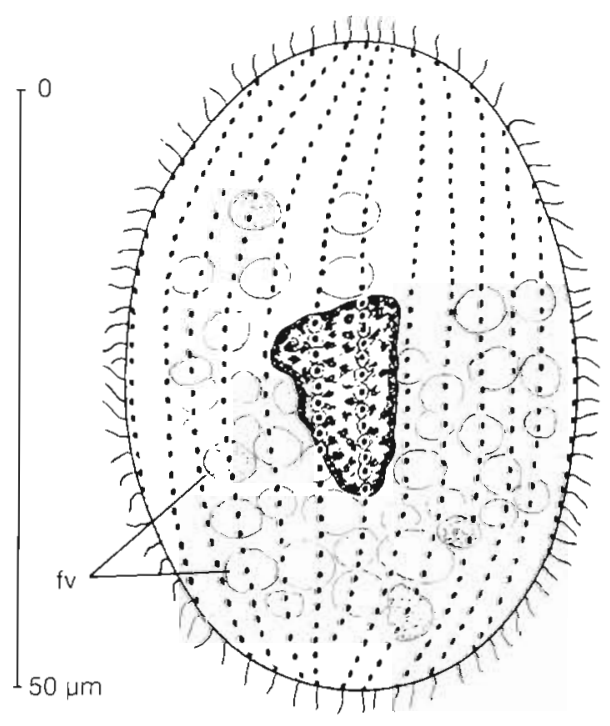

$\mathrm{L}$ dorsal
Fig. 1. Diagram of hymenostome ciliate belonging to Tetrahymena pyriformis species complex recovered from gills of freshwater crayfish Cherax quadricarinatus. Ventral and dorsal views of protargol umpregnated specimens. Scale bar $=50 \mu \mathrm{m}$ cvp: contractile vacuole pores; fv. food vacuoles; K1: first kinety = right postoral merld ian; L: left side; ma: macronucleus; mi: micronucleus; $\mathrm{m} 1, \mathrm{~m} 2, \mathrm{~m} 3$ : first, second and third adoral membranelles; $\mathrm{R}$ : right side; um: undulating membrane; s: preoral suture 
Table 1 Tetrahymena pyriformis. Morphometric characterization of hymenostome ciliate recovered from tissues of freshwater crayfish Cherax quadricarinatus. $\bar{x}$ : mean; SD: standard deviation; CV: coefficient of variation; $n$ : number of observations

\begin{tabular}{|c|c|c|c|c|c|c|}
\hline Character & $\bar{x}$ & SD & CV & Minımum & Maximum & n \\
\hline \multicolumn{7}{|l|}{ Body dimensions } \\
\hline Length $(\mu \mathrm{m})$ & 52 & 7.9 & 15.2 & 38 & 65 & 10 \\
\hline Width $(\mu \mathrm{m})$ & 36 & 5.7 & 15.6 & 28 & 45 & 10 \\
\hline \multicolumn{7}{|l|}{ Nuclei } \\
\hline Macronucleus length $(\mu \mathrm{m})$ & 13 & 2.4 & 17.6 & 10 & 16 & 10 \\
\hline Macronucleus width $(\mu \mathrm{m})$ & 10 & 1.5 & 15.1 & 8 & 12 & 10 \\
\hline Micronucleus diameter ( $\mu \mathrm{m})$ & 2.6 & 0.45 & 17.1 & 2.0 & 3.2 & 10 \\
\hline \multicolumn{7}{|l|}{ Somatic ciliature } \\
\hline Total number of kineties & 24 & 1.6 & 7.0 & 20 & 26 & 10 \\
\hline Number of post-oral kineties & 2 & - & - & 2 & 2 & 10 \\
\hline Length of first kinety, K1 ( $\mu \mathrm{m})$ & 35 & 4.2 & 12.2 & 30 & 42 & 10 \\
\hline Number of basal bodies in K1 & 25 & 4.2 & 16.8 & 20 & 32 & 10 \\
\hline \multicolumn{7}{|l|}{ Oral ciliature } \\
\hline Length of oral ciliary field $(\mu \mathrm{m})$ & 10.7 & 1.3 & 12.3 & 9 & 13 & 10 \\
\hline Width of oral ciliary field $(\mu \mathrm{m})$ & 5.5 & 0.6 & 11.3 & 4.8 & 6.5 & 10 \\
\hline Length of undulating membrane $(\mu \mathrm{m})$ & 8.2 & 0.7 & 8.1 & 7.0 & 8.9 & 10 \\
\hline Length of first membranelle, M1 ( $\mu \mathrm{m})$ & 6.8 & 0.4 & 6.4 & 6.0 & 7.2 & 10 \\
\hline Length of second membranelle, $\mathrm{M} 2(\mu \mathrm{m})$ & 6.0 & 0.4 & 6.3 & 5.2 & 6.5 & 10 \\
\hline Length of third membranelle, M3 ( $\mu \mathrm{m})$ & 3.2 & 0.2 & 8.2 & 2.9 & 3.7 & 10 \\
\hline
\end{tabular}

length and no elongate caudal cilium was detected. The ciliates contained an irregular ovoid to elliptical macronucleus located in the centre of the cell next to a single spherical micronucleus. On the basis of their morphological characteristics (summarized by Elliott 1973, Dragesco \& Dragesco-Kernéis 1986), the ciliates were identified as belonging to the species Tetrahymena pyriformis (Ehrenberg 1830) Lwoff 1947

\section{Histopathology}

Of the 3 crayfish examined by histology and found to be systemically infected by the ciliate, 1 was intensely co-infected with Psorospermium sp. and had a severe bacteremia. The other 2 crayfish had mild co-infections with Cherax quadricarinatus bacilliform virus (= Cherax baculovirus) and a bacteremia (Edgerton et al. 1995). The ciliates were more numerous in the latter 2 crayfish.

Ciliates were detected in histological sections of most organs and tissues from infected crayfish. They were recognized on the basis of their size, dense basophilic nuclei and prominent cell walls, which occasionally exhibited granular striations due to the presence of the somatic kineties (Figs, 3 to 7 ). Their cytoplasmic contents, however, were not well preserved and most sections of ciliates revealed extensive shrinkage artefacts and irregular aggregations of amorphous material. The majority of ciliates were detected in the haemocoel and haemal spaces within the tissues. They were frequently detected in the inter- tubular spaces of the hepatopancreas, often forming dense aggregates around tubules (Fig. 3). They were also commonly found in the main gill arches and were so densely packed in some instances that they filled the entire haemal sinus (Fig. 4). Heavy infections in the secondary lamellae often obscured any distinction between the afferent and efferent channels of the haemal sinus.

Ciliates were detected within the antennal gland, particularly in the large haemal sinuses surrounding the nephridial canal (Fig. 5), and occasionally in the haemal sinuses surrounding the labyrinth (Fig. 6), coelomosac and bladder. Numerous ciliates were found in the interstitial spaces and sometimes in the lumen of the myocardium (Fig, 7), but only rarely in the epicardium. They were frequently detected in the haemal sinuses between skeletal muscle bundles. Ciliates were found in the connective tissues surrounding the epithelium of the vas deferens (Fig. 8) and 1 organism was observed within the lumen of the vas deferens. Numerous ciliates were observed in the eye of 1 crayfish, and were most numerous in the retina at the base of the crystalline cones (Fig. 9), in the primary optic nerve region and in the lamina ganglionaris. Those organisms found in the retina contained dark granules similar to the proximal pigment in retinular cells (Johnson 1980)

Focal necrosis of tissues occurred in all infected crayfish. However, the necrosis was more extensive in those crayfish with less intense concomitant infections, particularly in the hepatopancreas (Fig. 10) and the nephridial canal of the antennal gland (Fig. 11). In 


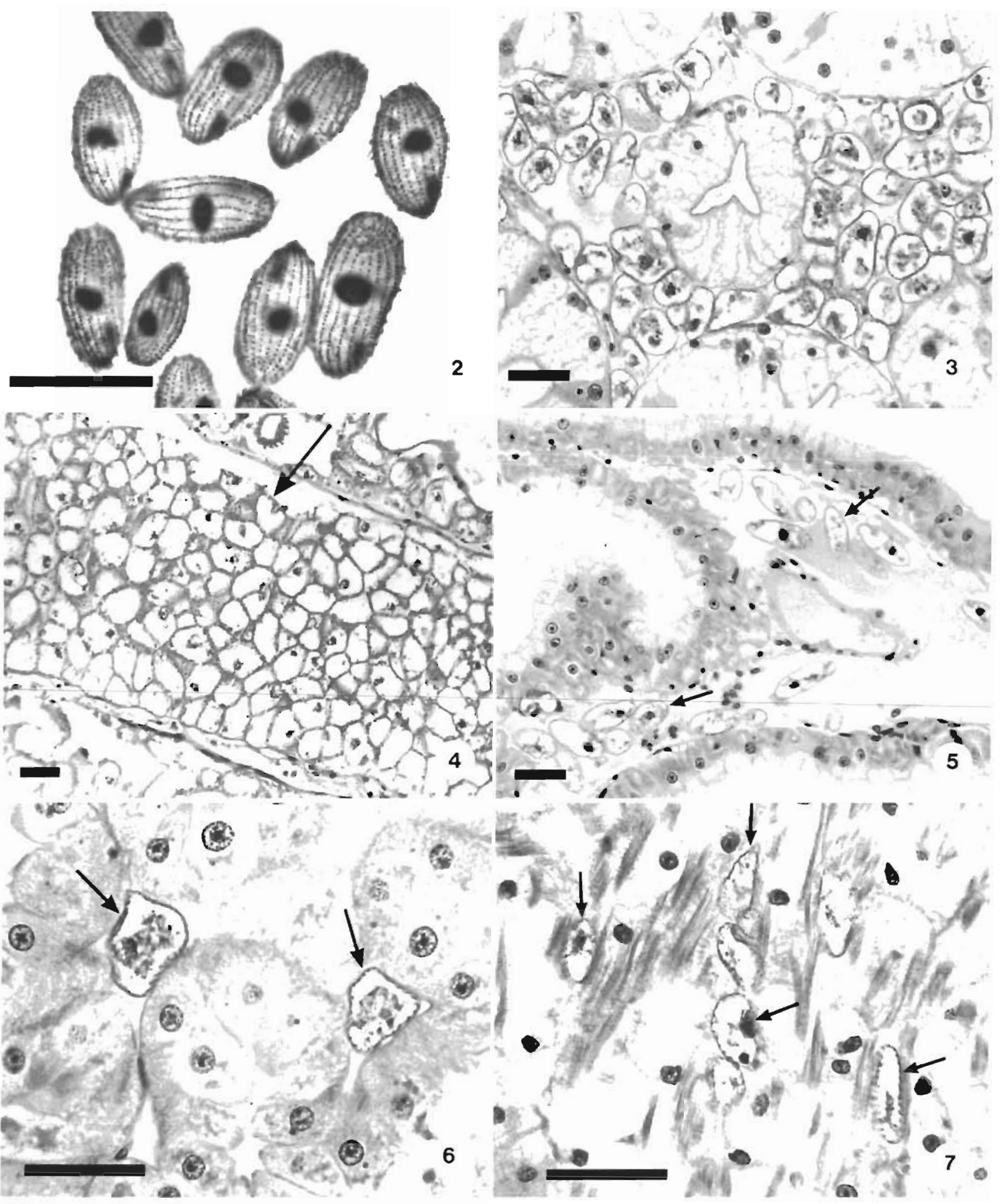

Figs. 2 to 7. Tetrahymena pyriformis from tissues of freshwater craytish Cherax quadricarinatus. Scale bars $=50 \mu m$. Fig. 2 . Cillates recovered from gill filaments. Protargol impregnation. Fig. 3. Section through cluster of ciliates in haemal spaces of hepatopancreas. H\&E. Fig. 4. Numerous vacuolated ciliates packed within haemal sinus (arrow) of gill filament. H\&E. Fig. 5. Ciliates (arrows) within haemal space surrounding the nephridial. canal of antennal gland. H\&E. Fig. 6. Two ciliates (arrows) in hat mal space of labyrinth region of antennal gland. H\&E. Fig. 7. Ciliates (arrows) located interstitially in myocardium. H\&E 


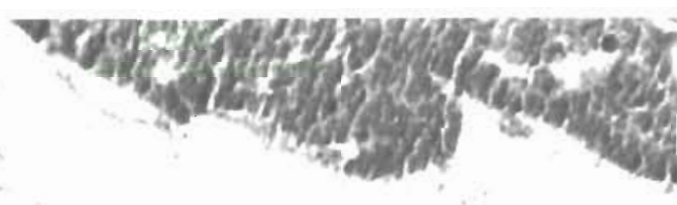

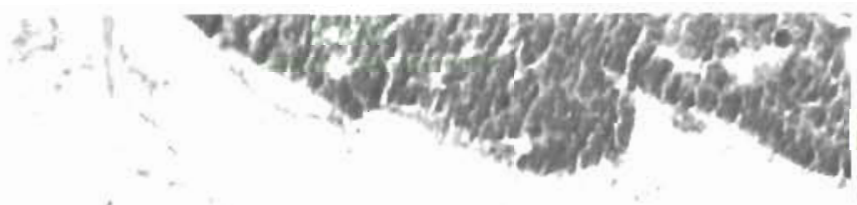

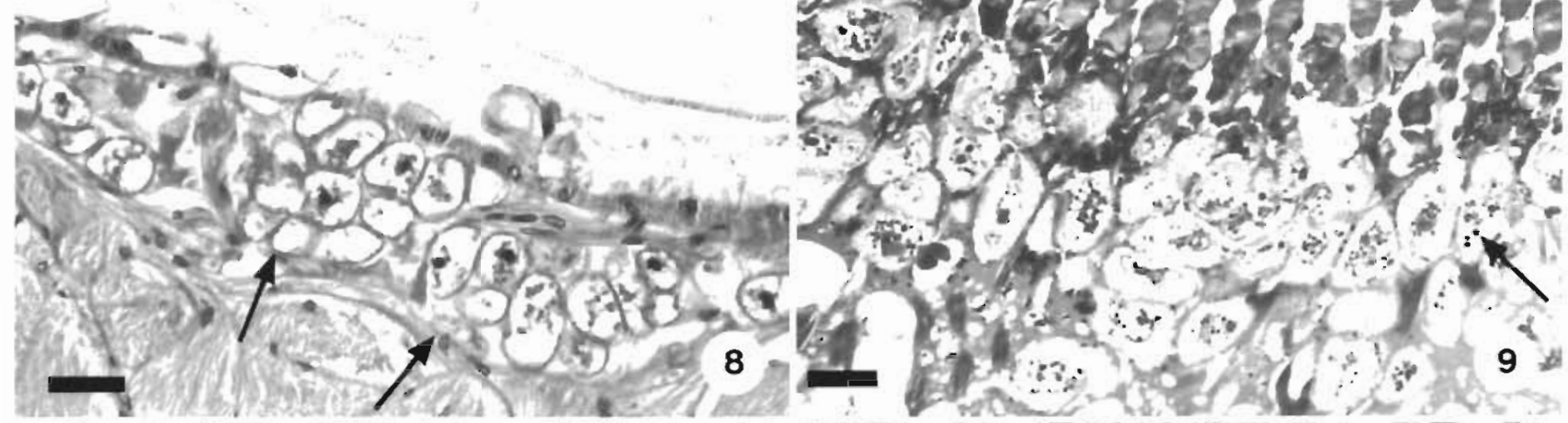
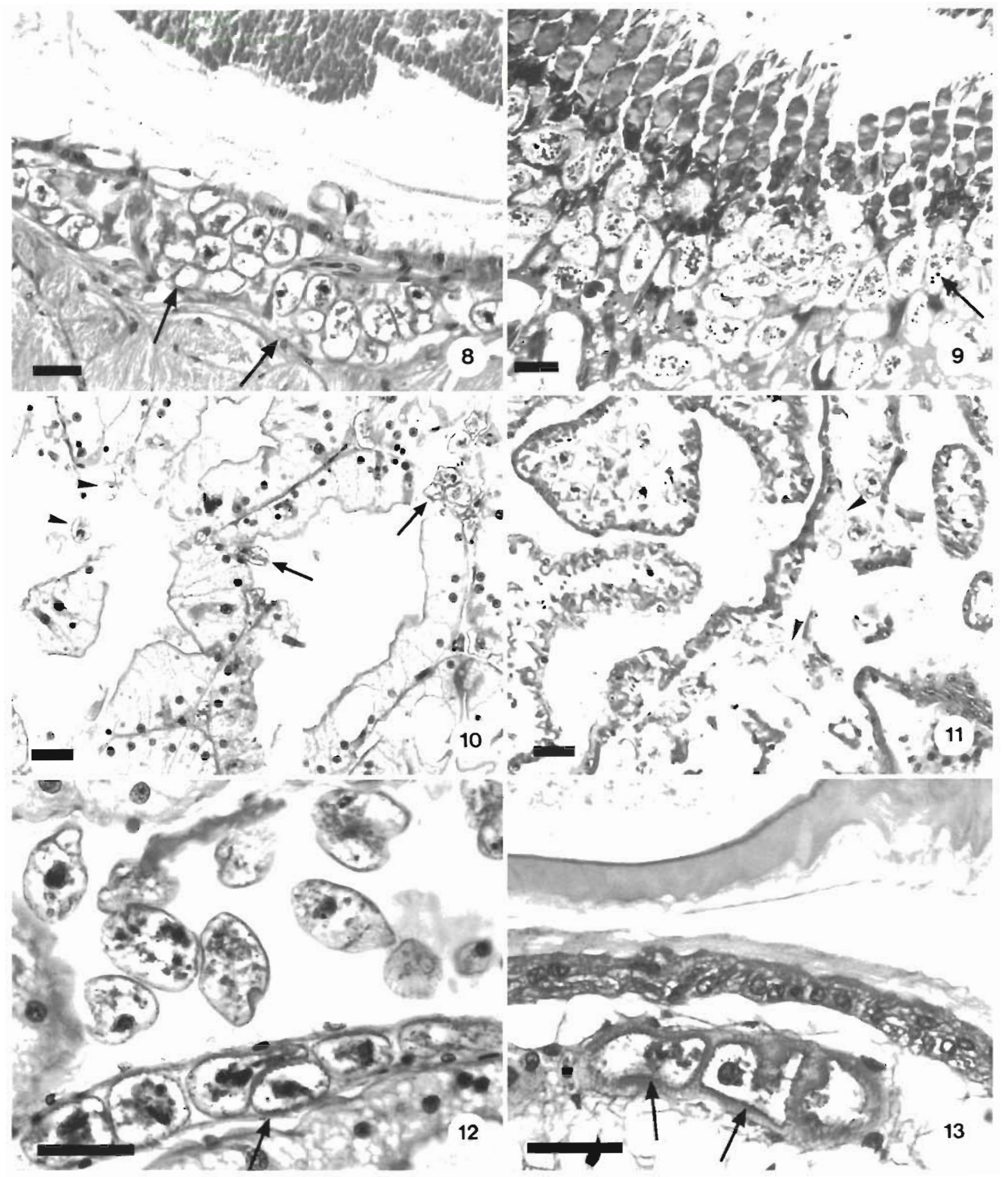
soles

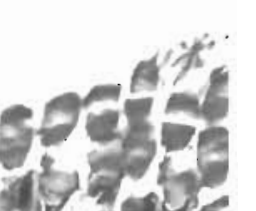

Figs. 8 to 13. Tetrahymena pyriformis from tissues of freshwater crayfish Cherax quadricarinatus. H\&E. Scale bars $=50 \mu m$. Fig. 8. Sections through ciliates (arrows) in connective tissue of vas deferens. Fig. 9. Ciliates in retina of eye, many containing dense black granules (arrow) similar to proximal pigment granules. Fig. 10. Necrotic area in hepatopancreas showing ciliates (arrows) in varying stages of penetration through epithelium. Fig. 11. Ciliates (arrowheads) located in necrotic area in nephridial canal of antennal gland. Fig. 12. Ciliates packed in haemolymph vessel (arrow) and lying free in haemocoel of hepatopancreas. 
these areas, the intima, endothelium and associated cells and connective tissue of the haemal system were diminished. Moreover, the ciliates had breached the hepatopancreatic tubule and nephridial canal and were in the lumen. Ciliates were more commonly seen in the haemolymph vessels of the crayfish with intense co-infections (Fig. 12). Ciliates invaded the connective tissues of various organs (Fig. 13). Circulating haemocytes were rare in the sections, and recent haemocytic whirling was not observed around the haemocytic nodules formed in response to the bacteraemias.

The lipid reserves in the hepatopancreas of the crayfish with minor concomitant infections were not depleted as numerous nutrient storage (R) cells containing lipid vacuoles were still present; nor was the hepatopancreas atrophied. These changes were, however, evident in the crayfish with acute concomitant infections. The exoskeletons of the infected crayfish were not soft or pale and there was no other evidence of recent ecdysis.

\section{DISCUSSION}

While many species of ciliated protozoa have been described as endozoic or ectocommensal organisms of aquatic hosts, few systemic infections have been recorded. Several hymenostome ciliates have been detected in the blood or internal organs of marine and freshwater fishes and various aquatic invertebrates, especially insect larvae (Elliott 1973). Systemic infections by 3 genera of scuticociliates have been described in crustacean hosts, all marine decapods, namely in crabs, lobster and prawns (Morado \& Small 1995). The present study represents the first record of systemic infections by ciliated protozoa in a freshwater decapod.

The ciliates were clearly hymenostomes with welldefined oral and somatic ciliature, the former comprising an undulating membrane and 3 membranelles and the latter containing 2 discrete postoral meridjans. No evidence was found of postoral thigmotactic areas, scutica or scutico-vestiges, which are characteristic of scuticociliates (Corliss 1979). Instead, their morphological characteristics were consistent with those of the genus Tetrahymena, in particular, those species belonging to the T. pyriformis complex (Elliott 1973, Corliss 1979, Dragesco \& Dragesco-Kernéis 1986, Foissner et al. 1994). This complex comprises T. pyriformis, $T$. setifera and $T$ chironomi, which are generally less than $60 \mu \mathrm{m}$ in length, have fewer than 24 somatic meridians, possess spherical micronuclei and do not form cysts (Elliott 1973). They differ from species belonging to the $T$ rostrata complex ( $T$. rostrata, $T$. limacis, $T$. corlissi and $T$. stegomyiae), which are typically greater than $60 \mu \mathrm{m}$ in length, have more than 25 somatic meridians, possess ovoid micronuclei and do form cysts. These species have often been recorded as histophagous parasites but only in fish, amphibians, slugs and snails (Elliott 1973, Corliss 1979). The ciliates were also different from those of the $T$. patula complex ( $T$. patula, $T$. vorax and $T$. paravorax), which are all free-living, greater than $100 \mu \mathrm{m}$ in length and form distinct microstome and macrostome morphotypes, the latter having large cytopharyngeal pouches (Elliott 1973).

The ciliates detected in the crayfish had 20 to 26 somatic meridians, 2 contractile vacuole pores located between kineties 5 and 6 and they lacked a caudal cilium. Within the Tetrahymena pyriformis complex, these characters are similar to those of $T$. pyriformis although smaller free-living forms with as few as 15 meridians have been described (Elliott 1973, Dragesco \& Dragesco-Kernéis 1986). They were different from those of $T$. setifera, which has a caudal cilium and 2 contractile vacuole pores located between kineties 8 and 9 . They were also different from $T$. chironomi, which has 23 to 28 meridians, 2 contractile vacuole pores located between kineties 6 and 9 and has only been found in chironomid larvae (Elliott 1973, Dragesco \& Dragesco-Kernéis 1986). T. pyriformis has been recorded throughout the world as a free-living organism commonly found in aquatic and terrestrial habitats ranging from freshwater ponds and streams to salt marshes and soils (Elliott 1973). However, it has also been found to be parasitic in the tissues of various vertebrate and invertebrate hosts. Infections have been reported in a variety of freshwater fish from Asia, Europe and North America (Elliott 1973, Hoffman 1978, Shulman 1984). Most infections have been confined to surface tissues and associated with skin lesions, raised scales, epidermal sloughing and extensive necrosis of the underlying musculature sometimes accompanied by neutrophil infiltration (Hoffman 1978). Systemic infections by $T$. pyriformis have only occasionally been detected in fish in association with moderate to extensive necrosis of various internal organs (Shulman 1984). More often, similar clinical and pathological signs have been associated with infections by $T$ corlissi and T. rostrata-like organisms in both marine and freshwater fish (Elliott 1973, Ferguson et al. 1987).

Despite the strong histophagous tendencies demonstrated by several Tetrahymena spp., they are considered to be facultative parasites with infections being accidental or opportunistic in nature. Ciliates are thought to gain entry to the host tissues through lesions or injuries in the external surfaces of the host (Elliott 1973). The portal of entry for ciliates into the crayfish is not known but most moribund crayfish 
were missing some appendages and many had small abrasions and cracks in their exoskeletons. Nevertheless, detailed experimental transmission studies are required to establish the actual route of infection. Previous attempts to infect the American freshwater crayfish Cambarus sp. with 5 different Tetrahymena spp. by inoculation into the haemocoel, the alimentary tract and into artificial wounds were unsuccessful (Thompson 1958).

Once within host tissues, the ciliates were actively histophagous but the actual mechanisms used to break apart host cells are not known. It has been suggested that ciliary action and extracellular lysosomes provide both mechanical and chemical means for disrupting tissues and cells (Armstrong et al. 1981). All systemic ciliates detected in crustaceans possess small subapical mouthparts and their oral cilia are used to sweep small fragments to the cytostome rather than to actively break apart cells. The role of the somatic ciliature in feeding processes is not known but many ciliates appeared to repeatedly probe clumps of cells with their anterior cilia. Further studies are required to determine the mechanisms by which histophagous ciliates disrupt host tissues and destroy cells. The ciliates were observed in various tissues throughout the crayfish and were often associated with extensive necrosis in several organs, particularly the hepatopancreas. Haemocytopenia has been reported to be characteristic of most systemic infections by scuticociliates in crustaceans (Bang et al. 1972, Sparks et al. 1982, Cawthorn et al. 1996) although lesions in other tissues have been described (Armstrong et al. 1981, Sparks et al. 1982). The ciliate infections in the crayfish were not considered to be long-standing (chronic or latent) as the hepatopancrea of the crayfish with only minor concomitant infections were not depleted of lipid reserves and there were no indications of organ atrophy. These changes in the 1 other crayfish were almost certainly a result of the acute concomitant infections. These findings suggest the recent acquisition of Tetrahymena pyriformis infections by the crayfish and the rapid development of acute clinical disease. Even if infections are opportunistic, the ciliates must be regarded as potential pathogens of freshwater crayfish. Their impact on both wild and cultured crayfish populations remains to be determined by future surveys and disease surveillance programs.

Acknowledgements. This study was supported in part by research grants awarded to Leigh Owens from the James Cook University (grant R-MRG-4473) and the Australian Research Council (grant A19332302). The authors also thank Laurie Reilly for his assistance in the preparation of histological sections. The advice of 3 anonymous reviewers is appreciated; one reviewer in particular made a significant contribution.

\section{LITERATURE CITED}

Armstrong DA, Burreson EM, Sparks AK (1981) A ciliate infection (Paranophrys sp.) in laboratory-held Dungeness crabs, Cancer magister. J lnvertebr Pathol 37:201-209

Bang FB, Audouin J, Leglise M (1972) Ciliate infection of the blood of the edible crab, Cancer pagurus, in holding tanks in Brittany, France. J lnvertebr Pathol 20:226-227

Cawthorn RJ, Lynn DH, Despres B, MacMillan R, Maloney R, Loughlin M, Bayer R (1996) Description of Anophryoides haemophila n.sp. (Scuticociliatida: Orchitophryidae), a pathogen of American lobsters Homarus americanus. Dis Aquat Org 24:143-148

Corliss JO (1979) The ciliated protozoa. Pergamon Press, Oxford

Couch JA (1978) Diseases, parasites, and toxic responses of commercial penaeid shrimps of the Gulf of Mexico and south Atlantic coasts of North America. Fish Bull 76:1-44

Culling CFA, Allison RT, Barr WT (1985) Cellular pathology techniques, 4 th edn. Butterworths, London

Dragesco J, Dragesco-Kernéis A (1986) Ciliés libres de l'Afrique intertropicale. Collection Faune Tropicale No. 26, Paris

Edgerton B, Owens L, Harris L, Thomas A, Wingfield M (1995) A health survey of farmed redclaw crayfish, Cherax quadricarinatus (von Martens), in tropical Australia. Freshwater Crayfish 10:322-338

Elliott AM (1973) Biology of Tetrahymena. Dowden, Hutchinson \& Ross, Stroudsburg

Ferguson HW, Hicks BD, Lynn DH, Ostland VE, Bailey J (1987) Cranial ulceration in Atlantic salmon Salmo salar associated with Tetrahymena sp. Dis Aquat Org 2:191-195

Foissner W (1991) Basic light and scanning electron microscopic methods for taxonomic studies of ciliated protozoa. Eur J Protistol 27:313-330

Foissner W, Berger H, Kohmann F (1994) Taxonomische und ökologische Revision der Ciliaten des Saprobiensystems. Band III: Hymenostomata, Prostomatida, Nassulida. Informationsberichte des Bayer. Landesamtes für Wasserwirtschaft, 1/94, München

Groliére CA, Leglise M (1977) Paranophrys carcini n.sp., cilie Philasterina recolte dans l'hemolymphe du crabe Cancer pagurus Linné. Protistologica 13:503-507

Hoffman GL (1978) Ciliates of freshwater fishes. In: Kreier JP (ed) Parasitic protozoa, Vol. II. Academic Press, New York, p 583-632

Johnson PT (1980) Histology of the blue crab, Callinectes sapidus: a model for the decapoda. Praeger, New York

Lom J, Dykova L (1992) Protozoan parasites of fishes. Elsevier, Amsterdam

Morado JF, Small EB (1994) Morphology and stomatogenesis of Mesanophrys pugettensis n.sp. (Scuticociliatida: Orchitophryidae), a facultative parasitic ciliate of the Dungeness crab, Cancer magister (Crustacea: Decapoda). Trans Am Microsc Soc 113:343-364

Morado JF, Small EB (1995) Ciliate parasites and diseases of Crustacea: a review. Rev Fisheries Sci 3:275-354

Shuiman SS (1984) Parasitic protozoa, Vol. 1 In: Bauer ON (ed) Key to parasites of freshwater fishes of the USSR, Vol 140. Keys to the fauna of the USSR. Nauka, Leningrad, p 252-280

Sparks AK, Hibbits J, Fegley JC (1982) Observations on the histopathology of a systemic ciliate (Paranophrys sp.?) disease in the Dungeness crab, Cancer magister. J Invertebr Pathol 39:219-228

Thompson JC (1958) Experimental infections of various animals with strains of the genus Tetrahymena. J Protozool 5: 203-205

Manuscript first received: March 27, 1996

Revised version accepted: June 18, 1996 